UDC 677.047

DOI: $10.15587 / 1729-4061.2016 .71242$

\begin{tabular}{|c|}
\hline 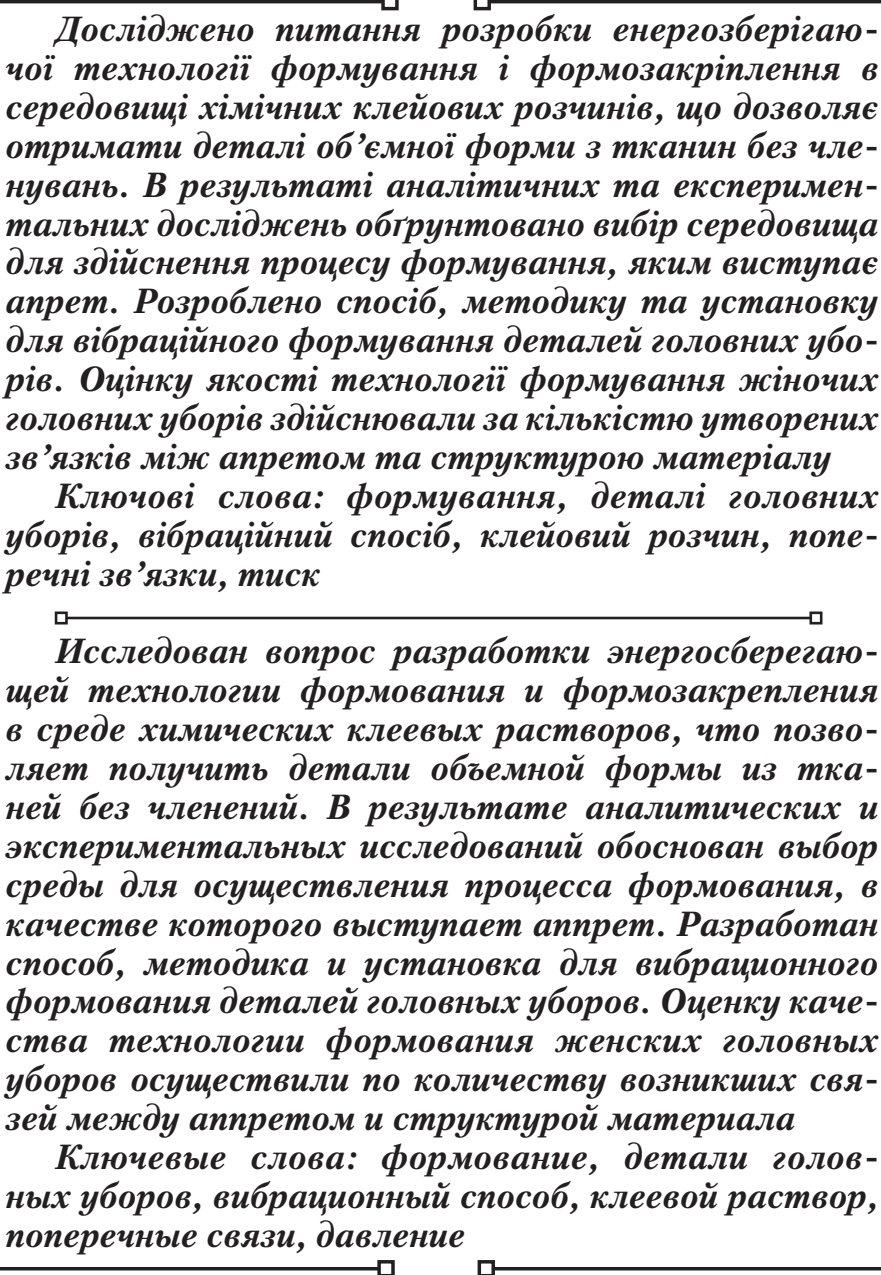 \\
\hline
\end{tabular}

Досліджено питання розробки енергозберігаючої технологї формування $і$ формозакріплення в середовищі хімічних клейових розчинів, що дозволяє отримати деталі об'ємної форми з тканин без членувань. В результаті аналітичних та експеримендля вібрачійного формування деталей головних уборів. Оцінку якості технологї формування жіночих головних уборів здійснювали за кількістю утворених 'язків між апретом та структурою матеріалу уборів, вібрачіинии спосіб, клейовий розчин, попе зон'язи, тиск

\section{DESIGN OF ENERGY-SAVING TECHNOLOGY OF SHAPING AND FIXING THE SHAPE OF HEADDRESSES PARTS}

\section{Introduction}

A costume nowadays includes: clothing, headwear, accessories, hairstyle, jewelry, cosmetics, and shoes. Clothes and shoes are made of textile, nonwoven fabrics and leather materials.

Headdresses, as well as clothing, are characterized by a variety of shapes depending on their service conditions, age and gender features, climatic conditions, properties of the original textile materials, etc. Headdress must meet demands of the consumer and possess high quality. Headdresses differ the most in complex spatial shape among the entire range of the above mentioned products.

One of the most important operational properties of clothing, headdresses and footwear is considered to be stability of their shape, which is mainly ensured by means of wet-andheat treatment (WHT) as well as static and dynamic influences on rough and fine structure of materials that are used.

It is known [1,2] that the shaping of the textile materials is a complex process, the aim of which is not only providing volumetric shape to a part, to a semifinished product, to a finished product, but its stable fixing. This process is based on the features of the textile material to accept and sustainably maintain the necessary spatial shape through various deformations.

The shaping of the textile material is performed by changing the angles between systems of threads, or by the deformation of fabric threads. The result is a change in the structure of the material. For a more stable deformation, which would remain during service, it is necessary to modify the fine structure of the fibres to remove or reduce the tension of the fibers and fix them in the new position, which provides stability of shape.

Given this, the relevant task is to design an energy-saving technology in the manufacture of headdresses.

\section{Analysis of scientific literature and the problem statement}

According to statistical data, the import of headdresses exceeds the amount of export. Among the reasons of this situation with headdress manufacturing is insufficient use of available raw resources, above all, the fabrics, low technological level of production, imperfection of technologies [3-5].

One of the promising directions of creating highly efficient manufacturing technology of products with complex volumetric shape is the use of dynamic and chemical methods of influence on the structure of the materials that are field, including the papers [6-8], as well as by other authors, contributed to the improvement of the processes of shaping and fixing the shape of parts of clothing, including headdresses.

Under conditions of modern production, the WHT is performed by using ironing and pressing equipment and in this case the thermal impact applies to only a defined area of a material. In manual mode, the pressure on a semi-finished product is ensured by the weight of an ironing set and the efforts of a presser. Required deformation of a part is achieved by such operations of the WHT as steaming and stretching. exposed to deformation. Results of scientific research in this 
This limits maintaining the required modes of processing and performing the appropriate operations with quality.

To ensure a sufficient level of quality of the volumetric parts during their shaping at presses it is important to set not only the rational modes and choose correct properties of amortized coatings, but adjust the mechanism of interaction between the top and bottom cushions (the punch and the matrix) that ultimately determines the shaping mechanism and the extent of deformation of textile material $[9,10]$.

It should be noted that the static methods of the shaping of the parts do not provide the necessary conditions for active work of "rough" structure of fabrics in the process of shaping. Thus, for the pressing equipment typical is: the presence of two rigid surfaces and static application of shaping loading with the simultaneous influence of heat and moisture [11]. Significant disadvantages of static methods of the shaping are uneven distribution of the force of the shaping on the entire surface due to the mismatch of shaping elements, complexity of regulating the overall pressing force and, especially, low activity of the "rough" structure of the material.

As for headdresses, manufacturing technology of producing wholly-shaped heads of headdress from felt is now well known. Analysis of several sources [12-14] indicates that the process of shaping is carried out predominantly by a static method.

Despite the fact that the volumetric shape of a work piece is by $80-90 \%$ produced on the stage of its fulling, the process of making a headdress is quite work consuming (the stage of preparation of a half-finished product lasts longer than 24 hours). That is why the need to search for alternative technologies is caused by the shortcomings of static shape forming methods: the presence of two rigid surfaces, static application of the loading, making it difficult to create a uniformly distributed force on the material, hard conditions of interactions in the system "shaping body - material" that is not able to provide the necessary conditions for the active work of "rough" structure of the material, large energy intensity and heat loss. Due to this reason, when looking for an alternative way of shaping parts of volumetric form, the attention should be paid to dynamic methods of shaping.

As a result of the search for dynamic methods of shaping, a number of scientists designed methods that partially eliminate the above-mentioned drawbacks of static methods of shape forming:

- membrane method of shape forming [15];

- creating technology of shape forming on the basis of the effects of centrifugal force in conjunction with microwave energy sources [16];

- vibropressing by using energy of electromagnetic waves [17];

- using dynamic methods of influence on material under conditions of different methods of supply of working media.

But in the existing technologies, the process of shaping and fixing the shape of a given form is performed separately, which leads to unnecessary energy and material costs.

Development of dynamic methods of shaping was carried out and improved in different directions:

1) by the number of surfaces of shaping (two - the punch and the matrix; two, one of which is not fully in contact with the entire surface of the material, and only in the area of transition from volumetric to plane surface, shaping on one shape forming surface);

2 ) by the nature of the force fields (a combination of static and dynamic loading; one- and two-side vibration; vibration, combined with vibro blow effect, centrifugal, hydro-dynamic loading);

3) by working medium (steam of different parameters, compressed air or steam, air with chemically active substances, technical water).

Promising for the development of a new method of shaping is the third direction that solves the shortcomings of the previous two. Thus, recently a series of studies has been conducted on the use of liquid-active working media (LAWM). The obtained results indicate the expedience of using LAWM in the shaping because under its action a significant improvement of the properties of textile materials occurs. This is due to the increase of mobility of "thin" and "rough" structure of the material, which is accompanied by a decrease in the coefficient of friction between the fibres in the system of threads. In addition, such a working medium under certain conditions produces evenly distributed loading on a shaping element, which can be static, dynamic and centrifugal.

This method can be laid to the basis of the design of energy-saving technology that will perform operations of shaping and fixing the shape in parallel. It differs fundamentally from the plane fixing of obtained deformations and allows performing operations of fixing the shape on the volumetric parts, including the heads of headdresses, reducing the cost of the product.

\section{The purpose and objectives of the study}

Performed studies set the goal of improving the quality of women's hats by improvement of the technology of their shaping and fixing their shape in the medium of chemical dressings.

To achieve the set goal, the following tasks were solved:

- to substantiate the choice of chemical means of activating the processes of shape forming and fixing the shape without additional thermal influence and to explore the mechanism of interaction of chemical substances on the "thin" and "rough" structure of fabric that is shaped;

- to explore the process of shaping and fixing the shape in one cycle of treatment based on the designed original installation;

- to determine the presence of created chemical bonds in the structure of the fibres of the material, which is processed by a dressing under different conditions of shaping.

\section{Materials and methods of the study of the process of shaping and fixing the shape of headdress parts}

\section{1. The studied materials and equipment used in the} experiment

The range of headdresses develops under the strong influence of new types of textile materials, the use of which enables to expand the model line of products on the basic shapes with regards to different style and artistic techniques.

The major features that influence the process of shaping and fixing the shape of parts of headdresses is a shaping ability of a fabric, the rigidity and drapeability of which must be considered when choosing materials for the manufacture of a headdress. Therefore, to design the technology of shaping and fixing the shape of volumetric parts of headdress we used fabrics of suit-and-coat range (Table 1). 
Table 1

Characteristics of studied fabrics

\begin{tabular}{|c|c|c|c|c|c|c|c|c|c|c|}
\hline \multirow{2}{*}{\begin{tabular}{|c}
$\begin{array}{c}\text { The name of the } \\
\text { fabric }\end{array}$ \\
Suit «Argon»
\end{tabular}} & \multirow{2}{*}{$\begin{array}{r}\text { Article } \\
23853\end{array}$} & \multirow{2}{*}{$\begin{array}{l}\text { Composition, \% } \\
\begin{array}{c}\text { wool }-67 \\
\text { viscose }-33\end{array}\end{array}$} & \multirow{2}{*}{$\begin{array}{c}\text { Interweaving } \\
\text { twill } 2 / 2\end{array}$} & \multirow{2}{*}{\begin{tabular}{|c|} 
Thickness, \\
mm, GOST \\
$12023-93$ \\
0,95
\end{tabular}} & \multicolumn{2}{|c|}{$\begin{array}{l}\text { Linear density of } \\
\text { threads per } 100 \\
\text { mm, } \\
\text { GOST 3811-92 }\end{array}$} & \multicolumn{2}{|c|}{$\begin{array}{c}\text { Linear fill, \% } \\
\text { GOST 3811-92 }\end{array}$} & \multirow{2}{*}{$\begin{array}{c}\text { Surface } \\
\text { fill, \% } \\
\text { GOST } \\
3812-92 \\
94,6\end{array}$} & \multirow{2}{*}{$\begin{array}{c}\text { Surface } \\
\text { density } \\
\text { m, g/m }{ }^{2} \\
\text { GOST } \\
3812-92 \\
542\end{array}$} \\
\hline & & & & & 220 & 230 & 76,2 & 80,1 & & \\
\hline $\begin{array}{c}\text { Suit } \\
\text { «Elegant» }\end{array}$ & 1372 & $\begin{array}{c}\text { wool }-70 \\
\text { viscose }-30\end{array}$ & twill 2/1 & 0,32 & 190 & 200 & 51,0 & 41,2 & 75,3 & 485 \\
\hline $\begin{array}{l}\text { Suit - coat } \\
\text { «Tayshet» }\end{array}$ & 23609 & $\begin{array}{c}\text { wool }-62 \\
\text { viscose }-33 \\
\text { kapron }-5\end{array}$ & twill $2 / 2$ & 1,12 & 280 & 280 & 71,4 & 65,6 & 50,4 & 416 \\
\hline Coat cashmere & 3406 & $\begin{array}{l}\text { wool }-45 \\
\text { viscose }-55\end{array}$ & twill 3/1 & 1,73 & 350 & 300 & 67,8 & 52,0 & 43,8 & 346 \\
\hline Coat & 3220 & $\begin{array}{c}\text { wool }-52 \\
\text { viscose }-38 \\
\text { caprine }-10\end{array}$ & twill 2/1 & 1,59 & 220 & 250 & 49,0 & 38,2 & 41,6 & 296 \\
\hline
\end{tabular}

For shaping the parts of headdresses in LAWM we designed the installation [18], which provides implementation of the three variants of vibration influence on a semi-finished product (Fig. 1).

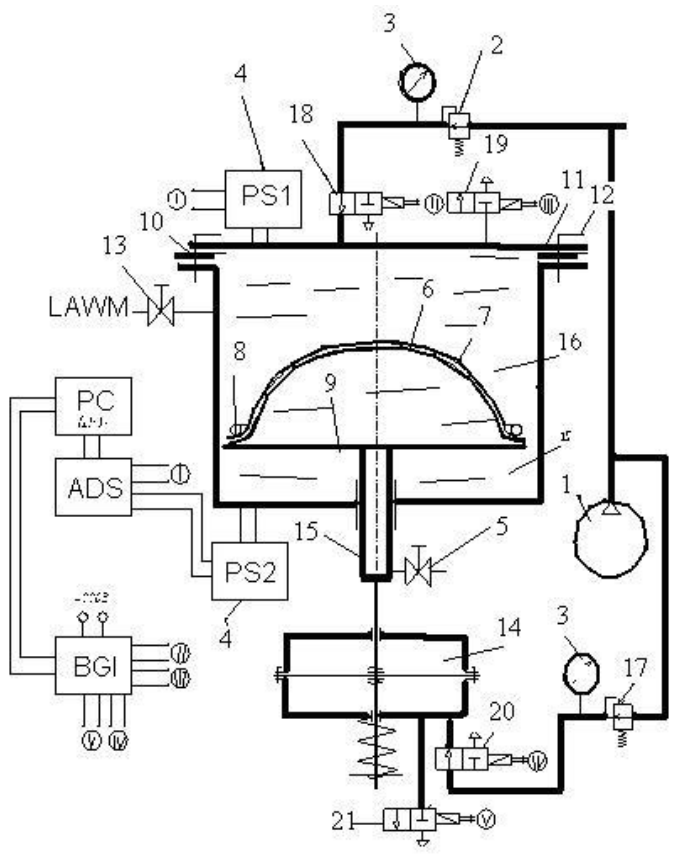

Fig. 1. Installation for the shaping of volumetric parts of headdresses in LAWM, where 1 is the compressor; 2, 17 is the stabilizer of air pressure (SAP); 3 is the manometer; 4 is the pressure sensor PS1, PS2; 5 is the drain valve; 6 is the shaping element; 7 is the workpiece; 8 is the spring-loaded ring; 9 is the platform; 10 is the gasket; 11 is the cover;

12 is the bolt; 13 is the feeder valve of LAWM; 14 is the membrane pneumatic drive; 15 is the rod; 16 is the chamber;

18,19 is the top, bottom inlet electromagnetic pneumatic distributor; 20, 21 is the top, bottom outlet electromagnetic pneumatic distributor

The advantage of the installation is the possibility of automated control according to the designed program by the algorithm of managing processes of air pulsation and the shaping element using LAWM. Instead of the top cushion, LAWM is used, which performs two functions simultaneously - preparing the materials to the shaping (plastification) and fixing the shape of received shape by broaching the structure of fabric by chemical bonds without additional heating of the material (a method of cold processing of materials).

The assessment of the mechanism of interaction between a dressing and fibre composition of materials, conducted on IR-spectrometer AVATAR-360 with IR-microscope Continuum under the following conditions:

- the range of spectrum register is $4000-650 \mathrm{~cm}^{-1}$;

- the resolution is $4 \mathrm{~cm}^{-1}$;

- the number of scans is 200 .

The specimens for the study were separated mechanically in a microscope field of view using the preparatory needle and tweezer. Registration of spectra was carried out in the "transmission-reflection» mode on a glass plate with a metallized surface.

\section{2. Methodology for conducting the process of shap-} ing headdress parts

A method of shaping volumetric parts in LAWM is as follows: the shaping occurs at a temperature that corresponds to the glassy state of the material $\mathrm{T}=20 \pm 3^{\circ} \mathrm{C}$.

The positions in the text are described according to Fig. 1. The workpiece 7 is fixed with a spring-loaded ring 8 on the shaping element 6 and platform 9 , which is then put on the rod 15 . Chamber 16 is closed and stable amount of LAWM is supplied to the working area through the valve 13. The air under pressure is also supplied to the chamber in order to compress the medium in $\mathrm{P}_{\mathrm{b}}$. In the variant (Fig. $3, b$ ), in addition to $\mathrm{P}_{\mathrm{b}}$, the LAWM is vibrated under certain air pressure $\mathrm{P}_{\mathrm{p}}$. The pulsation of air above is provided by two distributors 18 and 19, which are controlled by the PC through parallel port and the block of galvanic isolation (BGI). The value of air pressure, which is supplied from the compressor 1 , is controlled by a manometer and is set by using the SAP 2. To maintain the pulsation of the shaping element with a semi-finished product, a membrane pneumatic drive 14 is used. The air intake and outlet into the chamber is provided by two distributors 20 and 21 , the 
electromagnetic drive of which is run through the parallel port of the PC and BGI.

Air pressure in the chamber of pneumatic drive is set by using the SAP 17 and controlled by the manometer 3. After the shaping and extraction of LAWM through shaping element 6 with a semi-finished product 8 and the rod 15, drying and stabilisation of the received head of the headdress is performed in the drying chamber. The amplitude of pulsation of the rod in the working medium depends proportionally on the magnitude of set pressure in the membrane pneumatic drive 14. To measure $P_{p}$, there are two pressure sensors PS1 and PS2 (PCX5700) that contain the integrated operational amplifier, which facilitates their coordinated work with analogue-to-digital converter (ADC). To automate the process of shaping, a computer software was developed that allows managing the electromagnetic valves $18-21$, and processing and storing the data obtained from the ADC.

\section{5 . Results of the study of selection of chemical methods of activating the processes of shaping and fixing the shape}

An important factor in ensuring the quality of the shaping of women's headdresses is a reasoned selection of dressings that will provide the progress of deformational processes on the stage of shaping the goods and stabilization of the received shape after its completion. That is, a dressing should possess both plasticizing properties and hydrophobization effect after completion of the processes of shaping. With this aim, the research of 16 kinds of dressings of varying chemical composition was carried out in this work, which relate to four grades: based on the solutions of salts, water-soluble polymers, silicon resin and styrene-acrylic copolymers, pre-condensates of thermoreactive resins.

The assessment of the effectiveness of the specified chemically-active media was carried out by the indexes of stiffness, wrinkle resistance, shrinkage, hygroscopicity, water absorption, air permeability, processed materials (Fig. 2).

Given the presented data (Fig. 2), further studies were carried out using the LAWM No. 14 because this dressing meets all the established requirements [19]. This dressing has the following composition:

$-50-60 \mathrm{~g} / \mathrm{l}$ lakriteks;

- 50-60 g/l carbamol CES;

$-1-2 \mathrm{~g} / \mathrm{l}$ ammonium chloride.

The next step was to determine the influence of different working media (steam, water and dressing) on the shaping ability of the materials. The efficiency of the selected media was evaluated in terms of the components of the full deformation (Table 2), defined in the static and dynamic modes of loading for coat fabric 3220. As a result of the performed studies we found that the best deformational properties were provided by the dressing 14, because, if compared to other dressings, the proportion of the full deformation and the components are larger on average by $10-12 \%$.

Table 2

Consolidated indicators of deformation and its components under different methods of propulsion in the studied media

\begin{tabular}{|c|c|c|c|c|c|c|c|}
\hline \multirow{2}{*}{\multicolumn{2}{|c|}{$\begin{array}{l}\text { The name of the } \\
\text { material }\end{array}$}} & \multirow{2}{*}{ LAWM } & \multirow{2}{*}{$\begin{array}{l}\text { Swell- } \\
\text { ing, g }\end{array}$} & \multirow{2}{*}{$\begin{array}{c}\text { Complete } \\
\text { deforma- } \\
\text { tion, } \varepsilon, \mathrm{mm}\end{array}$} & \multicolumn{3}{|c|}{$\begin{array}{l}\text { Components of the full deformation, } \\
\mathrm{mm}(\%)\end{array}$} \\
\hline & & & & & conditionally & Elastic $\varepsilon_{\mathrm{el}}$ & plastic $\varepsilon_{\mathrm{pl}}$ \\
\hline \multicolumn{8}{|c|}{ Static loading } \\
\hline \multirow{18}{*}{$\begin{array}{c}\text { Coat } \\
\text { fabric } \\
\text { Art. } 3220\end{array}$} & & steam & 1,45 & 5,7 & $2,3(45,4)$ & $1,5(18,1)$ & $1,9(27,2)$ \\
\hline & base & water & 3,89 & 6,9 & $3,0(42,3)$ & $0,5(14,08)$ & $3,4(43,6)$ \\
\hline & & $\begin{array}{l}\text { dressing } \\
\text { № } 14\end{array}$ & 4,9 & 7,0 & $3,0(42,8)$ & $1,0(14,3)$ & $3,0(42,8)$ \\
\hline & & steam & 1,47 & 6,7 & $2,5(41,6)$ & $1,7(16,6)$ & $2,5(41,6)$ \\
\hline & weft & water & 3,92 & 7,5 & $2,2(34,7)$ & $2,3(21,7)$ & $3,0(43,4)$ \\
\hline & & $\begin{array}{l}\text { dressing } \\
\text { № } 14\end{array}$ & 5,05 & 8,0 & $1,0(12,5)$ & $2,0(25,0)$ & $5,0(62,5)$ \\
\hline & \multicolumn{7}{|c|}{ Vibration loading } \\
\hline & \multirow{3}{*}{$\begin{array}{l}\text { base } \\
\text { thread }\end{array}$} & steam & 1,62 & 7,1 & $2(28,1)$ & $2(28,1)$ & $3,1(43,6)$ \\
\hline & & water & 4,59 & 14 & $4(26,6)$ & $3(20,0)$ & $7(53,3)$ \\
\hline & & $\begin{array}{l}\text { dressing } \\
\text { № } 14\end{array}$ & 5,7 & 16 & $2(12,5)$ & $4(25,0)$ & $10(62,5)$ \\
\hline & \multirow{3}{*}{$\begin{array}{l}\text { weft } \\
\text { thread }\end{array}$} & steam & 1,69 & 7,8 & $2(25,6)$ & $2,5(32,0)$ & $3,3(42,3)$ \\
\hline & & water & 4,61 & 15 & $4(28,5)$ & $3(21,4)$ & $8(71,4)$ \\
\hline & & $\begin{array}{l}\text { dressing } \\
\text { № } 14\end{array}$ & 5,82 & 18 & $3(16,6)$ & $4(22,2)$ & $11(61,1)$ \\
\hline & \multicolumn{7}{|c|}{ Vibration loading and effect of pressure } \\
\hline & \multirow{2}{*}{$\begin{array}{l}\text { base } \\
\text { thread }\end{array}$} & water & 4,71 & 14,65 & $4,05(27)$ & $3,1(21,1)$ & $7,5(52,0)$ \\
\hline & & $\begin{array}{l}\text { dressing } \\
\text { № } 14\end{array}$ & 6,3 & 16,2 & $2(12,3)$ & $5(30,8)$ & $9,2(56,7)$ \\
\hline & \multirow{2}{*}{$\begin{array}{l}\text { weft } \\
\text { thread }\end{array}$} & water & 4,87 & 15,9 & $4(25,1)$ & $3,1(19,4)$ & $8,8(55,3)$ \\
\hline & & $\begin{array}{l}\text { dressing } \\
\text { № } 14\end{array}$ & 6,9 & 18,34 & $5(27,2)$ & $2,15(11,7)$ & $12,19(66)$ \\
\hline
\end{tabular}

It was found that under conditions of the dynamic loading, an increase in the deformational properties is achieved, compared to static loading, by $32 \%$ to $53 \%$ in the aqueous medium and by up to $60 \%$ - in the solution of dressing. In this case the amount of dressing with $\mathrm{M}=0,056 \mathrm{~g} / \mathrm{cm}^{2}$ increases in the processed materials during static processing up to $\mathrm{M}=0,141 \mathrm{~g} / \mathrm{cm}^{2}$ at dynamic loading with the simultaneous action of the pressure of the LAWM. The increase in mass is associated with the swelling of fibres, due to which the share of conditionally plastic deformation significantly increases, which determines the efficiency of the processes of shape provision. Based on these data, the most efficient method of improving the efficiency of the processes of shape formation and fixing the shape was displayed by the dressing No. 14 (solution of 50-60 g/l lakriteks, 50-60 g/l carbamol CES, 1-2 g/l ammonium chloride). 

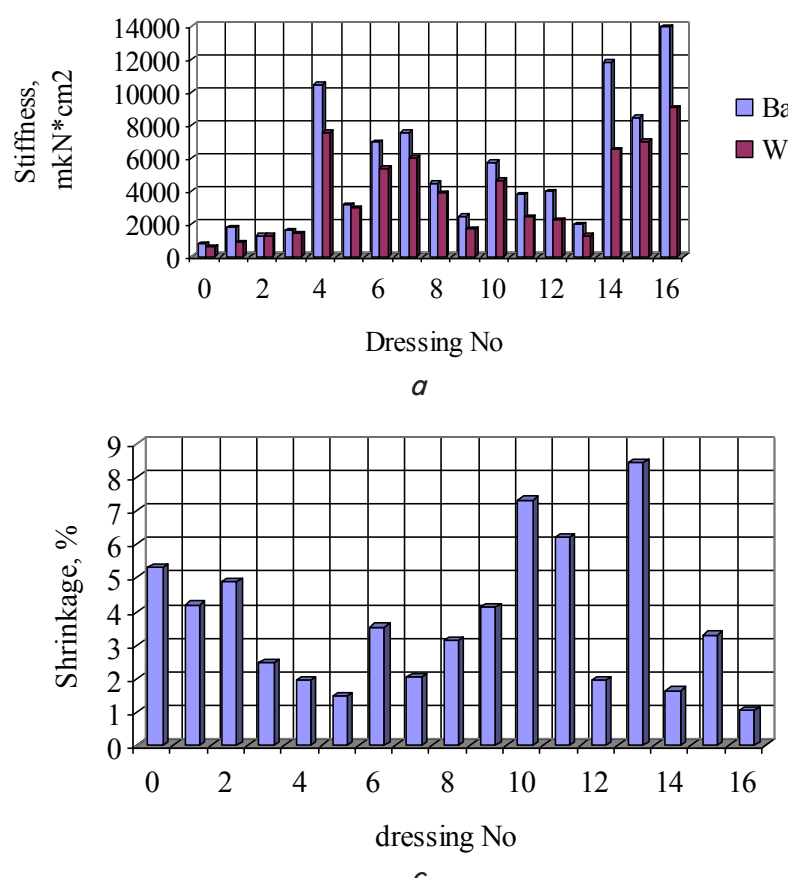

C

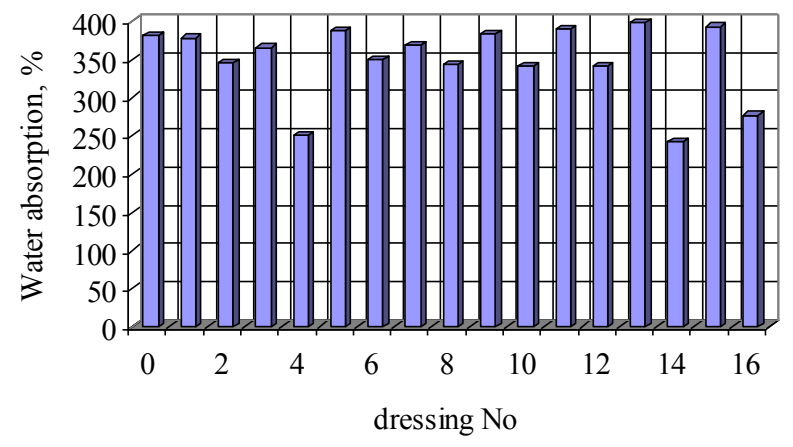

$e$

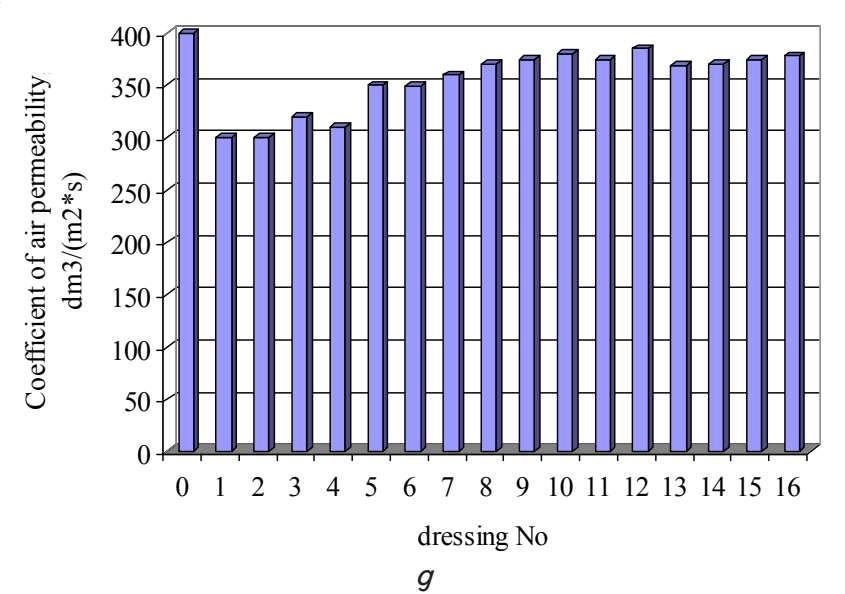

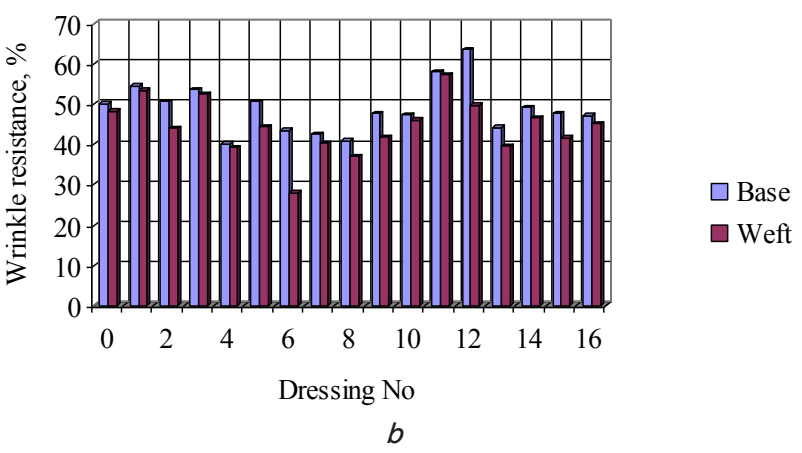
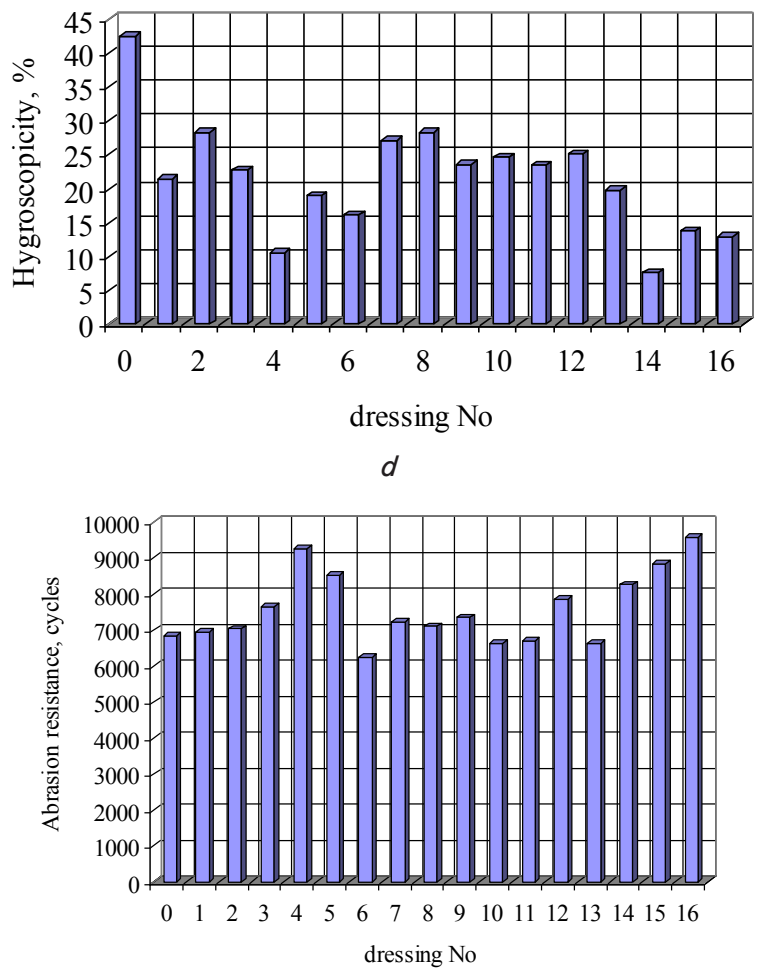

$f$

Fig. 2. Indicators of physical and mechanical properties of coat fabric (art. 3220) after processing by solutions of dressings: $a$-stiffness; $b$ - wrinkle resistance; $c$ - shrinkage; $d$ - hygroscopicity; $e$ - water absorption; $f$ - resistance to abrasion; $g-$ coefficient of air permeability

Establishing the efficient working medium enabled to perform the next, and not less important at that, task of studying the method of shaping. The choice of efficient way of shaping in the LAWM medium on the basis of three variants of vibration influence on the object to be processed (Fig. 3).
The first method involves the action of stable air pressure on LAWM while simultaneous reciprocating motion of the shaping element with certain frequency and amplitude. The second method involves the synchronization of movements of the shaping element and pulsating air, which acts on 
LAWM. The third way is different from the previous one in that the vibroshaping is carried out in the mode of asynchronous oscillations [20].
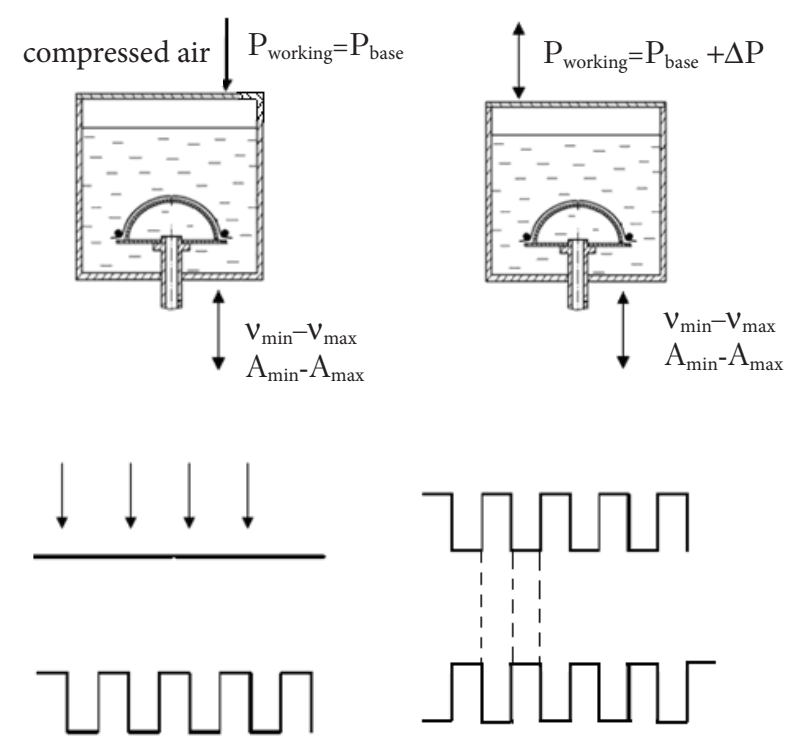

$a$ $b$
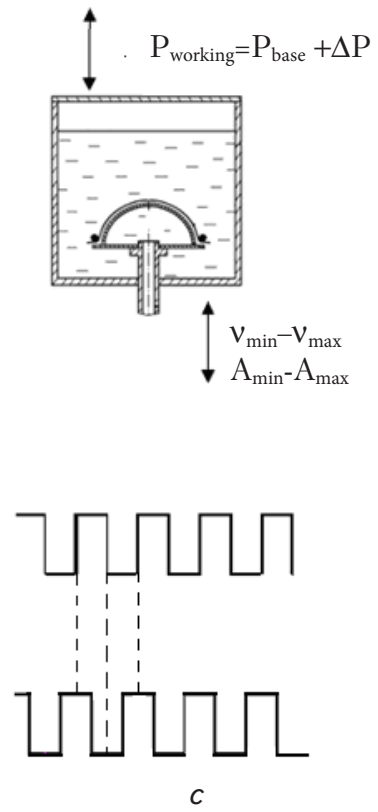

Fig. 3. Variants of vibration influence on a semi-finished product: $a$ - using the stable pressure of the LAWM; $b$ - using synchronous oscillations of the LAWM and the shaping element; $c$ - with the use of asynchronous oscillations of the LAWM and the shaping element

The assessment of the efficiency of the processes of shaping of the headdresses in the LAWM medium was carried out in the framework of realizations of the multifactor experiments. The coefficient of shape stability was adopted as the initial factor of assessment of the quality of the shaping. It was determined by the results of the assessment of the height of a shaped part compared to the height of the shaping element:

$$
\mathrm{K}_{\mathrm{f}}=\frac{\mathrm{h}_{\mathrm{p} 0}-\mathrm{h}_{\mathrm{p} 1}}{\mathrm{~h}_{\mathrm{p} 0}},
$$

where $h_{p 0}$ is the value of the height of a part after shaping, $m$; $h_{p 1}$ is the value of the height of a part after relaxation, $m m$.

The quality of the shaping is considered excellent if $K_{f} \leq 0,2$, good at $K_{\mathrm{r}} \leq 0,45$. A preliminary assessment of the influence of each of the factors on the index of $K_{\mathrm{f}}$ Statistical processing of the data enabled to arrive at one-factor dependencies $\mathrm{K}_{\mathrm{f}}=\mathrm{f}(\mathrm{A})$, $K_{\mathrm{f}}=\mathrm{f}(\mathrm{t}), \mathrm{K}_{\mathrm{f}}=\mathrm{f}(\mathrm{P}), \mathrm{K}_{\mathrm{f}}=\mathrm{f}(\mathrm{v})$, which are given in Table 3.

Table 3

Regression dependencies $k=f\left(x_{i}\right)$

\begin{tabular}{|c|c|c|}
\hline $\begin{array}{c}\text { Parameters of the } \\
\text { shaping process }\end{array}$ & Regression equation & $\begin{array}{c}\text { Correlation } \\
\text { ratio }\end{array}$ \\
\hline $\begin{array}{c}\text { Amplitude of } \\
\text { vibrations (A), } \mathrm{mm}\end{array}$ & $\mathrm{K}_{\mathrm{f}}=0,25-0,028 \mathrm{~A}$ & 0,989 \\
\hline $\begin{array}{c}\text { Time of shaping } \\
(\mathrm{t}), \mathrm{s}\end{array}$ & $\mathrm{K}_{\mathrm{f}}=0,336-0,0028 \mathrm{t}$ & 0,941 \\
\hline $\begin{array}{c}\text { Base pressure } \\
\text { LAWM (P), MPa }\end{array}$ & $\mathrm{K}_{\mathrm{f}}=0,3782-1,4 \mathrm{P}_{\mathrm{p}}+1,36 \mathrm{P}_{\mathrm{p}}{ }^{2}$ & 0,999 \\
\hline $\begin{array}{c}\text { Vibration } \\
\text { frequency }(\mathrm{v}), \mathrm{Hz}\end{array}$ & $\mathrm{K}_{\mathrm{f}}=0,344-0,045 \mathrm{v}+0,001 \mathrm{v}^{2}$ & 0,985 \\
\hline
\end{tabular}

Analysis of the received dependences made it possible to narrow the area of independent input data that were used in designing the plans of a multifactor experiment.

Comparative study of the processes of shaping and fixing the shape in the framework of the implementation of the matrices of experiment planning by three methods of shaping is presented on the example of coat fabric art. 3220.

After statistical processing of the results of the experiment, the rational values of technological parameters of the vibroshaping process are defined (Table 4).

Table 4

Results of the statistical processing of experimental data

\begin{tabular}{|c|c|c|}
\hline $\begin{array}{c}\text { The } \\
\text { name of } \\
\text { fabric }\end{array}$ & Regression equation & Rational values \\
\hline \multicolumn{3}{|c|}{ vibroshaping method using stable pressure of LAWM } \\
\hline \multirow{3}{*}{$\begin{array}{c}\text { Coat art. } \\
3220\end{array}$} & \multirow{3}{*}{$\begin{array}{c}\mathrm{K}_{\phi}=5,7-1,58 \cdot \mathrm{P}_{\mathrm{b}}+0,009 \cdot \mathrm{v}- \\
-0,003 \cdot \mathrm{t}+5,2 \cdot \mathrm{P}_{\mathrm{b}}^{2}+0,00033 \cdot \mathrm{t}^{2}\end{array}$} & $\mathrm{P}_{\mathrm{b}}=0,26 \mathrm{MPa}$ \\
\hline & & $\mathrm{t}=74 \mathrm{~s}$ \\
\hline & & $v=4,3 \mathrm{~Hz}$ \\
\hline \multicolumn{3}{|c|}{ vibroshaping method using synchronous oscillations of LAWM } \\
\hline \multirow{3}{*}{$\begin{array}{c}\text { Coat art. } \\
3220\end{array}$} & \multirow{3}{*}{$\begin{array}{c}\mathrm{K}_{\phi}=0,58-0,3 \mathrm{~A} \Delta \mathrm{P}-1,76 \mathrm{P}- \\
-0,07 \mathrm{~A}-0,01 v+5,2 \Delta \mathrm{P}^{2}+0,017 \mathrm{~A}^{2}\end{array}$} & $\Delta \mathrm{P}=0,17 \mathrm{MPa}$ \\
\hline & & $\mathrm{A}=2,3 \mathrm{~mm}$ \\
\hline & & $v=4,83 \mathrm{~Hz}$ \\
\hline \multicolumn{3}{|c|}{ vibroshaping method using asynchronous oscillations of LAWM } \\
\hline $\begin{array}{c}\text { Coat art. } \\
3220\end{array}$ & $K_{\phi}=0,31-0,056 \cdot \mathrm{T} / 5+0,008 \cdot \mathrm{T} / 5^{2}$ & $\begin{array}{c}\mathrm{T}=3 / 5 \\
\text { half-period }\end{array}$ \\
\hline
\end{tabular}

The analysis of regression equations showed that, regardless of the method of shaping, the determining factors that ensure the quality of the process of shaping are the pressure that creates the forces of shaping on the shaping element with the workpiece and the frequency of oscillations, which influences the activity of «rough» structure of the material. Since the equations can not be unified for all the studied fabrics, so it is 
advisable to submit separately rational modes of the process of shaping for each fabric and method of shaping (Table 5).

Table 5

Rational values of technological modes of vibroshaping of suit-and-coat fabrics in the medium of LAWM

\begin{tabular}{|c|c|}
\hline \multirow{2}{*}{$\begin{array}{l}\text { Rational values of parameters at } \\
\qquad \mathrm{K}_{\mathrm{f}}=0,2\end{array}$} & The name of fabric, article \\
\hline & Coat art. 3220 \\
\hline \multicolumn{2}{|c|}{ vibroshaping method using stable pressure of LAWM } \\
\hline Base pressure LAWM $\mathrm{P}_{\mathrm{b}}, \mathrm{MPa}$ & 0,26 \\
\hline Vibration frequency, $\mathrm{v}, \mathrm{Hz}$ & 4,3 \\
\hline час формування t, c time of shaping & 74 \\
\hline \multicolumn{2}{|c|}{ vibroshaping method using synchronous oscillations of LAWM } \\
\hline Vibration frequency $v, \mathrm{~Hz}$ & 4,8 \\
\hline Amplitude of vibrations A, mm & 2,3 \\
\hline pressure growth $\Delta \mathrm{P}, \mathrm{MPa}$ & 0,17 \\
\hline \multicolumn{2}{|c|}{ vibroshaping method using asynchronous oscillations of LAWM } \\
\hline $\begin{array}{c}\text { period of air supply into the chamber } \\
\text { of pneumatic drive } \mathrm{T}\end{array}$ & $3 / 5$ half-period \\
\hline
\end{tabular}

Defined rational modes for the studied fabrics within the suit-and-coat group at different methods of shaping do not have any specific trend. It was noted that for vibration method of shaping using stable pressure LAWM, the biggest impact is produced by base pressure and frequency of vibrations. With the increase of the mentioned factors from $0.22 \mathrm{MPa}$ to $0.3 \mathrm{MPa}$ and from $4.3 \mathrm{~Hz}$ to $8.0 \mathrm{~Hz}$, respectively, $\mathrm{K}_{\mathrm{f}}$ changes from 0.22 up to 0.14 . At a vibrating method of shaping using synchronous oscillations of LAWM, significant impact is exercised by increase in pressure $\Delta \mathrm{P}$. With the change in pressure from $0.15 \mathrm{MPa}$ to $0.28 \mathrm{MPa}$, $\mathrm{K}_{\mathrm{f}}=0.13-0.08$. When using asynchronous oscillations of LAWM, the decisive role will belong to the shift of the period of air supply to the pneumatic drive chamber $\mathrm{T}$, which is 3/5 half-period, $\mathrm{K}_{\mathrm{f}}=0,08-0,02$ (Fig. 4).

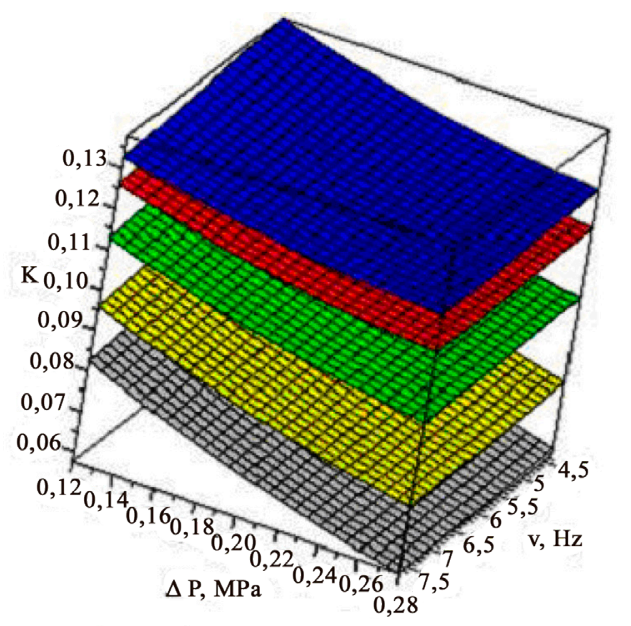

Levels of factors variation

$\square-+2 ; \square-+1 ; \square-0 ; \square--1 ; \square--2$

Fig. 4. Dynamics of change of response surface for the process of vibroshaping using synchronous oscillations of LAWM with vibration amplitude stabilized at $A$
An example of a graphic interpretation of response surfaces was built by the equation:

$$
\begin{aligned}
& \mathrm{K}_{\mathrm{f}}=0,58-0,3 \mathrm{~A} \Delta \mathrm{P}-1,76 \mathrm{P}- \\
& -0,07 \mathrm{~A}-0,01 \mathrm{v}+5,2 \Delta \mathrm{P}^{2}+0,017 \mathrm{~A}^{2} .
\end{aligned}
$$

Each of the surfaces was obtained by stabilizing the amplitude of vibration $A$ at one of five levels $(+2 ;+1 ; 0 ;-1 ;-2)$.

This graphical interpretation clearly identifies the area of rational values of vibration method of shaping using synchronous oscillations of the LAWM, where

$$
\mathrm{K}_{\mathrm{f}} \rightarrow \min .
$$

The quality of the shaping is determined not only by matched vibroshaped part of the shaping element, but also by its stability over time. This is determined by the relaxation processes that occur in the part.

The assessment of the relaxation processes was carried out by the indicator $\mathrm{K}_{\mathrm{f}}$. Results of the analysis indicate that rather high quality $\left(\mathrm{K}_{\mathrm{f}} \leq 0,28\right)$ is achieved virtually by all methods of the shaping. But according to the indicators of relaxation, the vibration method of shaping using asynchronous oscillations of the LAWM is preferable, which provides the minimal percentage of relaxation, that is a shape stability over time.

The assessment of mechanism of interaction between a dressing and the material was carried out. The assessment was carried out by the indicators of IR spectra. Fig. 5 presents the IR spectra of coat fabric before and after processing by a dressing under different conditions.

The analysis of absorption spectra showed that when applying the dressing, in the area from 3600 to $3200 \mathrm{~cm}^{-1}$, the reduction of absorption of carboxyl groups occurs, especially when processing in the presence of vibration loadings. This is probably due to the interaction of carboxyl groups with oksymetolon groups of dimethyl urea. Strengthening of the intensity of absorption band in the area of $1520 \mathrm{~cm}^{-1}$ suggests the interaction of macromolecules of wool with a suturing agent.

Increase in the intensity of absorption band with frequency $900 \mathrm{~cm}^{-1}$ characterizes the depth of the process of shaping of reticulated structures. Thus, changes in the area of $1600 \mathrm{~cm}^{-1}$ in the spectrum of the material processed by styrene-acrylic dispersion with a suturing agent indicates the formation of hydrogen bonds between the acrylic fiber, dimethyl urea and acrylic copolymer. The process of suturing happens more intensively during a vibration loading on a textile material.

We chose a value of crosslinks that are formed by a dressing between adjacent macromolecules of viscose as the criteria for quality assessment of the process of stabilization of the shape.

By using the Kjeldahl method, in the beginning we defined the content of nitrogen in the fibres of fabrics treated by a dressing under normal conditions and at vibroshaping, $\mathrm{W}_{\mathrm{N}}=11.2 \%$ and $\mathrm{W}_{\mathrm{N}}=7.1 \%$, respectively. Based on these data, the number of crosslinks was calculated, where nitrogen is associated with the structure of viscose. Due to vibration loadings, the number of such links grows by $2-2.5$ times, which guarantees the stability of the formed shape. 
Intensity of adsorption, \%

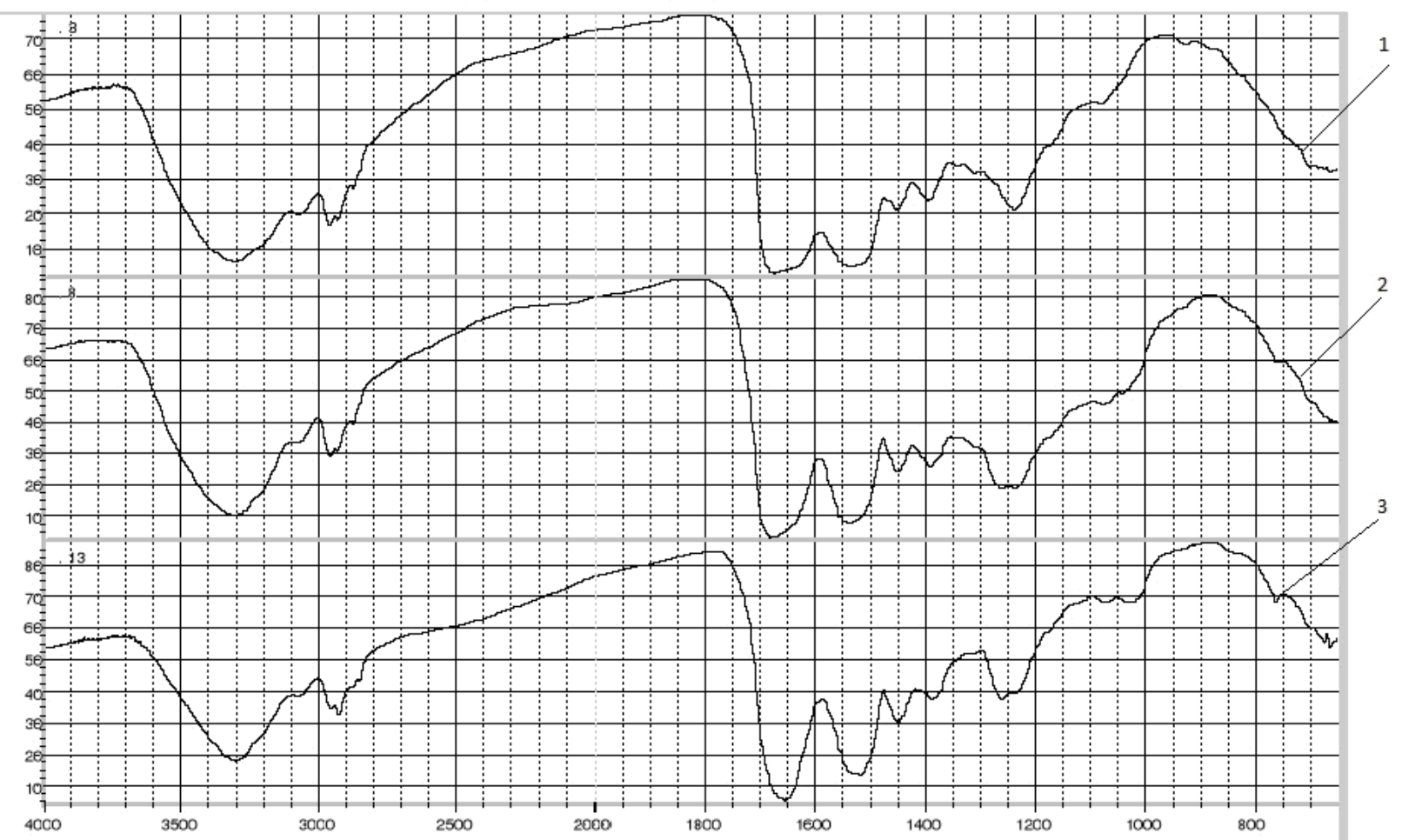

Fig. 5. IR spectra of textile material: 1 - semi-wool coat fabric art. 3220; 2 - processed by styrene-acrylic dispersion at free absorption; 3 - processed by styrene-acrylic dispersion at vibration shaping method using asynchronous oscillations of LAWM

\section{Discussion of the results of the study of using dressings as medium for shaping the headdress heads}

The basis of the designed technology is a hypothesis on the shaping and simultaneous fixing the shape of headdress parts by dynamic loadings and at different phase-frequency characteristics of the LAWM pressure.

Since the criterion of selection of a dressing is a shape stability and hydrophobicity of the provided specimens of materials, then the changes in such properties as stiffness, wrinkle-resistance, hygroscopicity and water absorption were mainly addressed. Analysis of diagrams of the obtained results (Fig. 2) shows that the greatest stiffness is displayed by materials, impregnated with dressings 4 , 14, 15, 16, wrinkle-resistance - processed by 2, 3, 11, 12 . Indicators of water absorption and hydropobicity should be minimal, which is typical for the fabrics impregnated with dressings 4, 14, 16. The least prone to shrinkage are materials, processed by dressings $5,12,14,15$. The index of air-permeability should be close to the raw material this is provided by dressings $4,14,16$. Taking it into consideration, for further research of the processes of shaping and fixing the shape, the dressing 14 was selected from the proposed list of solutions.

After analyzing the data from Table 2, we see that the change in the working medium from steam to water with a dressing allows increasing the total deformation up to $32 \%$, and the change of the force field from static to dynamic leads to the increase in deformation by $52.7 \%$ in water and by $60.4 \%$ in the solution of a dressing. Adding pressure of LAWM to vibration loadings increases full deformation by $4.6 \%$, because due to pressure, the viscosity of the solution decreases and its penetration into the structure of the material improves.
Thus, we studied the essential methods of improving a deformation capacity of the material, which affect the process of shaping and fixing the shape of garment parts.

So, during the design of the method of shaping, LAWM pressure and vibration loadings will be crucial for the process of shaping, because this combination significantly increases the share of plastic deformation of selected materials. This research allowed selecting the optimal composition of LAWM for implementation of the process of shaping and fixing the shape, which is the dressing 14 .

Let us explain the physical meaning of the obtained mathematical models (Table 3 ) that characterize the correlation between the coefficient of shape stability and the studied factors. The parameter $\mathrm{K}_{\mathrm{s}}$ is not influenced by the factors proportionally, which is indicated by a quadratic effect. The biggest impact is by $\mathrm{P}_{\mathrm{b}}$ and the frequency of oscillations $v$ of the workpiece. Less impact is by the time of the process of shaping, the smallest impact on the process is by the amplitude of oscillations $A$.

To determine the extreme (minimal) value of a mathematical model, equations are differentiated by each independent variable. Conversion of the mathematical model of the process of vibration shaping into canonical form makes it possible to receive a visual representation of the patterns of change in a criterion of optimization.

To do this, by using the program Excel, we carried out the analysis of response functions and rationalized the process of shaping (Table 5). The task of rationalization was to find the values of the factors that belong in the field of accepted values $\mathrm{X}_{\mathrm{i}} \in[-2 ; 2]$ in which the output parameter reaches $\mathrm{y}=0,1-0,2$.

Having analyzed the IR spectra of textile material (Fig. 5), the data indicate that the use of the given composition of dressing to stabilize the shape of the parts of headdresses made of textile materials with wool-viscose content leads to increased strength, shape stability and other physical- 
mechanical indicators. Because the parameters are maintained during service, this is explained by creation of chemical bonds between functional groups of cellulose and components of a shape-fixing dressing and determines the nature of the distribution of dressing in the structure of the material.

In the course of service the headdresses are subject to chemical cleaning. Therefore, it became necessary to conduct the testing of headdresses during chemical cleaning at the company TOV TPP "Universal”, city of Khmelnitskiy (Ukraine). The research indicate that the use of designed dressing allows processing the headdress with shape-stable and hydrophobic treatment, since the indicator of stiffness remains 17 times larger, while hydropobicity is two times higher than in the original material.

Practical importance of the research results is that the designed installation for vibration shaping allows receiving seamless parts of volumetric shape without a temperature influence.

By using the shaped parts of headdress heads, we produced models of women's hats (Fig. 6). Quality indicators of the manufactured headdress confirm the efficiency of the conducted research. The designed technology allows reducing labour costs by $53.8 \%$ compared to the technology of headdresses sawn heads and by $12.7 \%$ compared to a hydrodynamic method of manufacturing.
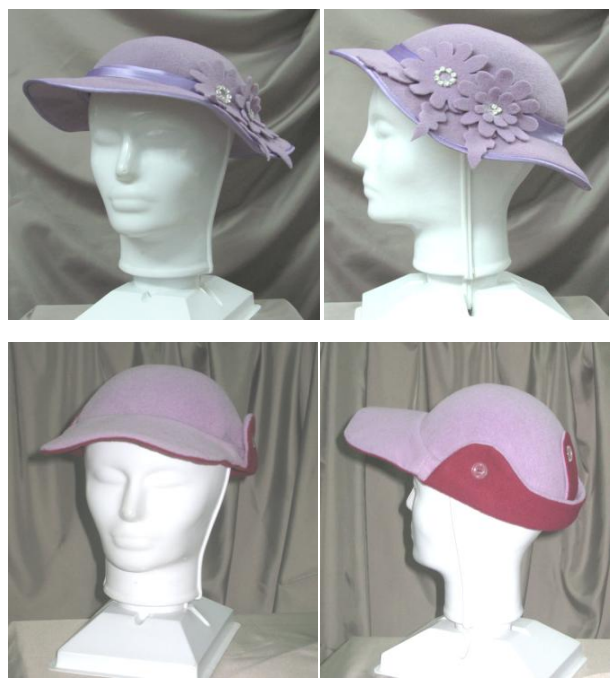

Fig. 6. Models of women's headdresses
Unlike the hydrodynamic method, when using vibration method of shaping, the energy costs reduction amounted to $0.12 \mathrm{~kW} / \mathrm{h}(49 \%)$. The results of the research are implemented at TOV Hust-Filz, Zakarpatska Oblast, Ukraine.

\section{Conclusions}

1. The conducted research, theoretically and experimentally, substantiated the selection of a chemical method of activating the processes of shaping and fixing the shape, which is a liquid-active medium. A dressing is a universal method of implementation in one cycle of the processes of shaping and fixing the shape of parts of headdresses made of wool and semi-wool fabrics without additional temperature influence.

2. A vibration method was designed, which has three implementation variants and an installation for the vibroshaping and fixing the shape of parts of headdresses in the LAW M medium. A comprehensive study of the efficiency of three variants of vibroshaping and fixing the shape of parts of headdresses in the medium of LAWM were performed. As a result of the research we obtained graphical dependencies which are described mathematically. The main rational parameters of the process of shaping arise from these dependencies: the frequency of vibration $v=4.8 \mathrm{~Hz}$, the amplitude of vibration $\mathrm{A}=2.3 \mathrm{~mm}$, increase in pressure $\Delta \mathrm{P}=0.17 \mathrm{Mpa}$, the period of the air supply to the chamber of a pneumatic drive $\mathrm{T}=3 / 5$ half-period. The headdress head, shaped under these parameters, displays high quality of this part $\left(K_{\mathrm{f}} \leq 0,28\right)$. The designed method allows exploring the process of shaping and fixing the shape in one cycle of treatment.

3. Based on IR-spectroscopy, we studied the mechanism of interaction of binding substances of a dressing with a fabric and the nature of their distribution in the structure. Under the action of vibration shaping using asynchronous oscillations of LAWM, their quantity increased by $51 \%$ on average, compared to the raw material, which indicates the stability of the formed shape.

All these studies made it possible to design energysaving technology of shaping and fixing the shape of headdresses parts.

\section{References}

1. Bereznenko, S. M. Osnovy teorii resursozberihaiuchykh tekhnolohichnykh protsesiv formuvannia ta formozakriplennia detalei shveinykh vyrobiv z vrakhuvanniam anizotropii tekstylnykh materialiv [Text] / Bereznenko, S. M. - Kyiv, 2002. - 372 p.

2. Koshevko, Yu. V. Udoskonalennia protsesu formuvannia ta zakriplennia formy detalei zhinochykh holovnykh uboriv iz tkanykh materialiv [Text] / Yu. V. Koshevko. - Khmelnytskyi, 2010. - 170 p.

3. Mokshyna, O. V. Vlazhno-teplovaia obrabotka shveinikh yzdelyi [Text] / O. V. Mokshyna, L. V. Fedyna, V. Y. Ochkurenko // Visnyk SNU im. V. Dalia. - 2007. - Vol. 71. - P. 287-290.

4. Yuferova, L. V. Razrabotka metodov otsenky y yssledovanye formuemosty y formoustoichyvosty elastychnikh kamvolnykh tkanei [Text] / L. V. Yuferova. - Kostroma, 2005. - 170 p.

5. Zhao, L. Factors affecting recovery of PTT shape memory fabric to its initial shape [Text] / L. Zhao, L. Qin, F. Wang, H. Hin Chuah // International Journal of Clothing Science and Technology. - 2009. - Vol. 21, Issue 1. - P. 64-73. doi: 10.1108/09556220910923764

6. Tashpulatov, S. Sh. Tekhnolohyia formoustoichyvoi obrabotky detalei shveinikh yzdelyi s polymerno-kollahensoderzhashchymy kompozytsyonnimy materyalamy [Text] / S. Sh. Tashpulatov, T. Zh. Kadyrov, S. Y. Ysmaylova. - Tashkent: Fan va texnologiya, 2012. - $151 \mathrm{p}$.

7. Ghane, M. A small deflection model for yarn bending in a plain weave fabric [Text] / M. Ghane, I. Azimpour, S. A. Hosseini Ravandi // International Journal of Clothing Science and Technology. - 2011. - Vol. 23, Issue 5. - P. 310-320. doi: 10.1108/09556221111166248 
8. Feughelman, M. Natural protein fibers [Text] / M. Feughelman // Journal of Applied Polymer Science. - 2002. - Vol. 83, Issue 3. P. 489-507. doi: 10.1002/app.2255

9. Mazloumpour, M. Study of wicking behavior of water on woven fabric using magnetic induction technique [Text] / M. Mazloumpour, F. Rahmani, N. Ansari, H. Nosrati, A. H. Rezaei // Journal of The Textile Institute. - 2011. - Vol. 102, Issue 7. - P. 559-567. doi: 10.1080/00405000902952200

10. Topalbekiroğlu, M. The effect of weave type on dimensional stability of woven fabrics [Text] / M. Topalbekiroğlu, H. Kübra Kaynak // International Journal of Clothing Science and Technology. - 2008. - Vol. 20, Issue 5. - P. 281-288. doi: 10.1108/09556220810898890

11. Sneddon, J. N. Making sense of consumers wool apparel preferences [Text] / J. N. Sneddon, J. A. Lee, G. N. Soutar // Journal of The Textile Institute. - 2012. - Vol. 103, Issue 4. - P. 405-415. doi: 10.1080/00405000.2011.580545

12. Haharyna, S. V. Proektyrovanye y proyzvodstvo shveinikh holovnikh uborov [Text] / S. V. Haharyna, S. V. Bokova. - Rostov-naDonu: Fenyks, 2003. - 383 p.

13. Benltoufa, S. Determination of yarn and fiber diameters after swelling using a capillary rise method [Text] / S. Benltoufa, F. Fayala, S. B. Nasrallah // Journal of The Textile Institute. - 2012. - Vol. 103, Issue 5. - P. 517-522. doi: 10.1080/00405000.2011.589573

14. Silin, R. I. Osnovy stvorennia vibratsiinoho obladnannia z pulsuiuchym robochym tilom nezalezhno vid haluzi vykorystannia [Text] / R. I. Silin, A. I. Hordieiev, R. S. Silin, Ye. A. Urbaniuk // Visnyk KhNU. - 2013. - Vol. 2. - P. 7-16.

15. Berger, W. Textile Faserstoffe: Beschaffenheit und Eigenschaften [Text] / W. Berger, H. Faulstich, P. Fischer, A. Heger, H.-J. Jacobasch, A. Mally, I. Mikut. - Berlin: Springer, 1993. - 432 p. doi: 10.1007/978-3-642-77655-7

16. Stoyanova Germanova-Krasteva, D. Influence of terry fabrics structure on dynamic sorption [Text] / D. Stoyanova GermanovaKrasteva, G. Dimitrova Kandzhikova, A. Grigorov Bochev // nternational Journal of Clothing Science and Technology. - 2013. Vol. 25, Issue 4. - P. 243-256. doi: 10.1108/09556221311326284

17. Müller, S. Werkstoffkennwerte [Text] / S. Müller. - Fakultät Maschinenwesen: Ingenierarbeit/Dresdeden, 1990. - 123 p.

18. Pat. 51683 UA, MPK A41N 41/00 V29S55/00. Ustanovka dlia formuvannia detalei holovnykh uboriv obiemnoi formy v ridynnoaktyvnomu robochomu seredovyshchi [Text] / Koshevko Yu. V., Kushchevskyi M. O., Prybeha D. V. - Declareted 11.02.2010; published: 26.07.2010; Biul. 14. -9 p.

19. Pat. 48799 UA, MPK A 41N 5/00 D 06F 73/00. Sklad apretu tekstylnoho materialu z nadanniam hidrofobnoi obrobky vyrobam [Text] / Koshevko Yu. V., Kulakov O. I. Kushchevskyi M. O. - Declareted 28.09.2009; published: 12.04.2010; Biul. 7. - 3 p.

20. Pat. 46767 UA, MPK A 41N 5/00 D 06F 73/00. Sposib vibroformuvannia detalei shveinykh vyrobiv obiemnoi formy v ridynno-aktyvnomu seredovyshchi [Text] / Koshevko, Yu. V., Kushchevskyi, M. O., Prybeha, D. V. - Declareted 01.06.2009; published: 11.01.2010; Biul. 1. -3 p. 